Pre-Print: Journal of Private International Law, vol. 9, num. 2, 2013, pp. 191-217

\title{
COMMON EUROPEAN SALES LAW (CESL) AND PRIVATE INTERNATIONAL LAW: SOME CRITICAL REMARKS*
}

\author{
Sixto A. SÁNCHEZ-LORENZO**
}

\begin{abstract}
A. INTRODUCTION
The Proposal for a Regulation of the European Parliament and of the Council on a Common European Sales Law (PCESL) ${ }^{1}$ is the modest return on decades of efforts towards the unification of European Private Law. This optional instrument ${ }^{2}$ (Article 3), limited to some cross-border contracts, seems to be the only feasible legislative outcome, which shatters the hopes of the European Parliament and of leaders such as Christian von Bar, who speculated in 2010 that it was the dawn of a European Civil Code. It might be too much effort for such a humble result. But the future will show whether a Common European Sales Law is a milestone that announces the advent of more ambitious achievements.

The Proposal will apply exclusively to cross-border transactions. That is why it must be examined from the point of view of Private International Law and related to rules on conflicts-of-laws already in force within the European Union, particularly to the Rome I Regulation on the law applicable to contractual obligations.

The overall objective of the proposal is "to improve the establishment and the functioning of the internal market by facilitating the expansion of cross-border trade for business and cross-border purchases for consumers. This objective can be achieved by making available a self-standing uniform set of contract law rules including provisions to protect consumers, the Common European Sales Law, which is to be considered as a second contract law regime within the national law of each Member State".

Thus, the CESL constitutes an attempt to avoid transaction costs derived from legal diversity within the European Union. However, the character and scope of CESL rules, together with their complex interaction with European conflict-of-laws rules and the substantive acquis, leads to a scenario of legal uncertainty. This means that the intended objective will not be achieved and, in certain cases, that consumer protection is sacrificed in

\footnotetext{
* This article is an updated and revised version of the contribution published by the author in XI Anuario Español de Derecho Internacional Privado, 2011, 25-61, under the title: "La Propuesta de Reglamento relativo a una normativa común de compraventa europea y el Derecho internacional privado".

${ }^{* *}$ Professor of Private International Law at the University of Granada (Spain).

${ }^{1}$ COM (2011) 635 final 2011/0284 (COD).

2 This optional character constitutes a central idea of the Proposal, beyond legal techniques, as it reveals the principle of contractual freedom that underlies the base of this regulation and poses essential dilemmas, given that it is linked with a sphere of protected rights such as those of consumers (see M Schmidt-Kessel, "Der Vorschlag der Kommission für ein Optionales Instrument - Einleitung", Ein einheitliches europäisches Kaufrecht? (Eine Analyse des Vorschlags der Kommission) (Munich, 2012) 2-6.

3 PCESL, 4 and Article 1 PCESL.
} 
favour of traders' interests. In order to illustrate this critical conclusion, the character and scope of CESL rules will firstly be analysed (B). Secondly, the application of CESL rules will be considered in cases of an express or implied choice of law $(C)$ and then in the absence of such a choice (D). Finally, further reflections will focus on the application of overriding mandatory rules $(\mathrm{E})$ and on the seminal question of the applicable law to interpret contracts $(\mathrm{F})$.

\section{B. CHARACTER AND SCOPE OF CESL RULES}

Substantive rules included in Annex I (CESL) of the PCESL perfectly fit, as a technique of private international law, within the category of "special substantive rules" (Sondersachrecht). They provide a direct and substantive regime of cross-border contracts that form its sphere of application (Article 4 PCESL). Moreover, this regime is "special" in the sense that it is different from that provided by the rules of national laws which must be applied in domestic cases. ${ }^{5}$ Thus it is quite clearly described in the Explanatory Memorandum of the Proposal: "The Common European Sales Law will be a second contract law regime within the national law of each Member State". ${ }^{6}$

Secondly, rules included in the CESL do not work as "independent" substantive rules, but as a set of rules depending on conflict rules on contractual obligations ${ }^{7}$, that is on the interaction with the Rome I Regulation. The Explanatory Memorandum makes this very clear from the beginning:

"The Rome I Regulation and Rome II Regulation will continue to apply and will be unaffected by the proposal. It will still be necessary to determine the applicable law for cross-border contracts. This will be done by the normal operation of the Rome I Regulation.

(...) Where the parties have agreed to use the Common European Sales Law, its rules will be the only national rules applicable for matters falling within its scope. Where a matter falls within the scope of the Common European Sales Law, there is thus no scope for the application of any other national rules. This agreement to use the Common European Sales Law is a choice between two different sets of sales law within the same national law and does therefore not amount to, and must not be confused with, the previous choice of the applicable law within the meaning of private international law rules." 8

\footnotetext{
${ }^{4}$ See P Mankowski, "Der Vorschlag für ein Gemeinsames Europäisches Kaufrecht (CESL) und das Internationale Privatrecht", RIW, 2012/3, 97, 98-99.

${ }^{5}$ See JC Fernández Rozas \& S Sánchez Lorenzo, Derecho internacional privado, 6th ed., (Madrid, 2011) 127.

6 PCESL, 7.

${ }^{7}$ See on this distinction JC Fernández Rozas \& S Sánchez Lorenzo, supra n 5, 127-128.

8 PCESL, 6-7. Recital 10 insists: "The agreement to use the Common European Sales Law should be a choice exercised within the scope of the respective national law which is applicable pursuant to Regulation (EC) No 593/2008 or, in relation to pre-contractual information duties, pursuant to Regulation (EC) No 864/2007 of the European Parliament and of the Council of 11 July 2007 on the law applicable to non-contractual obligations (Regulation (EC) No 864/2007), or any other relevant conflict of law rule. The agreement to use the Common European Sales Law should therefore not amount to, and not be confused with, a choice of the applicable law within the meaning of the conflict-of-law rules and should be without prejudice to them. This Regulation will therefore not affect any of the existing conflict of law rules." The Committee on Legal Affairs of the European Parliament proposed: "The agreement to use the Common European Sales Law results from a choice between two different regimes within the same national legal order. This choice therefore does not amount to, and should not be confused with, a choice between two national legal orders within the meaning of the conflict-of-law rules and should be without prejudice to them. This Regulation will therefore not affect any of the existing conflict of law rules such as those contained in Regulation (EC) No 593/2008", Draft Report on the proposal for a
} 
In a sense, thus, the PCESL envisages, as a criterion of spatial application, a similar formula as is included in Article 1(1)(b) CISG: the Convention applies to contracts for the sale of goods between parties whose places of business are in different States "when the rules of private international law lead to the application of the law of a Contracting State." But the PCESL does not provide an additional formula of direct application as stipulated in Article 1(1)(a) CISG, which becomes applicable where the place of business of the parties are in different contracting States, even if the applicable law is the law of a third State. The CESL will only be applied in those cases when the applicable law, as lex contractus, is the law of a Member State. In such an event, the determination of applicable substantive rules leads to a fork in the road: the application of the internal rules of that national law or, only if the parties have agreed, the application of CESL rules.

Moreover, CESL rules cause an interaction not only with the Rome I Regulation, but also with the Rome II Regulation. In fact, the whole of chapter 2 in part II (Articles 13 to 29) deals with pre-contractual information that traders must provide to consumers and with the responsibility derived from a breach of these mandatory rules during a precontractual stage or negotiation. Indeed, it is a matter excluded from the scope of application of the Rome I Regulation [Article 1.2(i)] and included in Article 12(1) of the Rome II Regulation. The reference in this Article to the lex contractus minimizes the problems, insofar as the application of the contract law of a Member State accompanied by a choice of the CESL would lead to a direct application of these rules. However, as the PCESL itself states (Article 11), the application of Articles 13 to 29 remains limited to cases where a contract is effectively concluded, while Article 12 of the Rome II Regulation is applied regardless of such effective conclusion. Consequently, if the contract is never concluded, pre-contractual responsibility from breach of obligations considered in Articles 13 to 29 CESL will be submitted to the national law applicable under Article 12 of the "Rome II" Regulation. Nevertheless, a doubt remains about the scope of Article 11 PCESL. One can understand, as explained above, that Article 11 PCESL entails a restriction of the sphere of application of the whole CESL rules, but it is also possible to argue that Article 11 PCESL implies a mere limitation of the sphere of application of Articles 13 to 29 themselves. In this last case, pre-contractual responsibility where the contract has not been concluded would also be submitted to CESL rules, but not to Articles 13 to 29. The gap would be solved through the interpretation rule of Article 4, that is under the principles implied in the CESL itself, with no reference to national laws. ${ }^{10}$ Another reason for complexity came from a characterization of pre-contractual responsibility as "contractual" or "non contractual", which can be determined by an interpretation of the CESL itself if the case, whatever it may be, falls into its sphere of application. But characterization as "non-contractual" also determines the application of the "Rome II" Regulation itself, which requires an autonomous concept of "noncontractual obligation" (Recital 11). A European concept of "non-contractual obligation" should be the same in relation to both legal texts.

In any case, it is quite clear that the PCESL does not implement the possibility opened up in Recital 14 of the Rome I Regulation: "Should the Community adopt, in an

regulation of the European Parliament and of the Council on a Common European Sales Law (COM(2011)0635 - C7-0329/2011 - 2011/0284(COD)), 8.

9 See M Schmidt-Kessel, "Anwendungsbereich, Ausgestaltung der Option und andere Fragen zur Verordnung", Ein einheitliches europä̈sches Kaufrecht? (Eine Analyse des Vorschlags der Kommission) (Munich, Sellier, 2012) 36-43.

${ }^{10}$ See M Schmidt-Kessel, supra n 9, p. 38; S. Whittaker, "The Optional Instrument of European Contract law" (2011) European Review of Contract Law 371, 396-397; C Wendehorst, Common European Sales Law (CESL) -Commentary- (ed. R. Scbulze) (Baden-Baden, 2012) 71-72. 
appropriate legal instrument, rules of substantive contract law, including standard terms and conditions, such instrument may provide that the parties may choose to apply those rules". The so-called "2 $8^{\text {th }}$ Regime" would have allowed the choice of a European (nonnational) legal system as applicable law (lex contractus). Such an alternative would have provided legal certainty and predictability and would have avoided at least the complexity derived from the " $2^{\text {nd }}$ Regime". As analysed below, a choice by the parties of CESL rules does not have a "conflict-of-laws" significance and, as the Explanatory Memorandum declares, neither prevents, nor affects, a choice of the applicable law under Article 3 of the Rome I Regulation, which will always be narrowed down to a generic choice of a national law. However, it is surprising that, beyond the Explanatory Memorandum and Recitals of the PCESL, no article in the proposal establishes expressly the dependence of the CESL application on the fact that the law of a Member State should be applied to the contract under private international law rules.

Consequently, under a " $2^{\text {nd }}$ Regime" the application of CESL requires firstly a crossborder transaction and secondly that the lex contractus is the law of a Member State. But these are not the only spatial conditions for applying CESL rules. Its spatial application is not limited to European transactions, but extends to some extra-European transactions under certain limits ${ }^{11}$. Under the provision of Article 4 PCESL, in commercial contracts (B2B) the cross-border character is determined by the residence or the establishment ${ }^{12}$ (or intervenient agency or branch of the company) of the parties in different States, one of which must be sited in a Member State. In case of consumer contracts (B2C), it is enough that the habitual residence of the trader is different from the address indicated by the consumer, the delivery address or the billing address, one of them being located in a Member State.

The legal basis of the PCESL (Article 114 TFEU) is apparently not in harmony with the optional character of the CESL. ${ }^{13}$ It also calls for a reflection on its ultra vires scope in

${ }^{11}$ Explanatory Memorandum clarifies: "Finally, the proposal is consistent with the international trade policy of the Union, in that it does not discriminate against parties from third countries who could also choose to apply the Common European Sales Law as long as one party to the contract is established in a Member State" (PCESL, 7). Recital 14 specifies: "The use of the Common European Sales Law should not be limited to cross-border situations involving only Member States, but should also be available to facilitate trade between Member States and third countries. Where consumers from third countries are involved, the agreement to use the Common European Sales Law, which would imply the choice of a foreign law for them, should be subject to the applicable conflict-of-law rules".

12 For companies or other bodies, corporate or unincorporated, habitual residence means "the place of central administration", while for traders who are natural persons it means the "principal place of business" (Article 4.4 PCESL).

13 See especially the Max Planck Institute for Comparative and International Private Law, "Policy Options for Progress towards a European Contract Law" (2011) Rabels Zeitscbrift 388-396. Most authors prefer the legal basis provided by Article 352 TFEU or even by Article 81 TFEU, given its limitation to cross-border transactions but the latter could only be a subsidiary legal basis: See H Fleischer, "Optionales europäisches Privatrecht ("28. Modell”)" (2012) Rabels Zeitschrift 235, 243-244. M Schmidt-Kessel, supra n 2, 12-15; JJ Kuipers, "The Legal Basis for a European Optional Instrument" (2011) European Review of Private Law 545-564; PC Müller-Graff, "Der Introitus des optionalen Europäischen Kaufrechts: Das erste Kapitel im Kontext von Kodifikationskonzept und Primärrecht", Ein einheitliches europäisches Kaufrecht? (Eine Analyse des Vorschlags der Kommission), Munich, 2012, 57-61; PC Müller-Graff, "Ein fakultatives europäisches Kaufrecht als Instrument der Marktordnung?", Der Entwurf für eine optionales europäsiches Kaufrecht (Munich, 2012) 34-35; HC Grigoleit, "Der Entwurf für ein Gemeinsames Europäisches Kaufrecht: Funktionsbedingunden, EU-Kompetenz und Perspektiven", Gemeinsames Europäisches Kaufrecht für die EU? (Analyse des Vorschlags der Europäischen Kommission für ein optionales Europäisches Vertragsrecht vom 11. Oktober 2011), Remien, Herrler, Limmer Hrsg. (Munich, 2012) 67-85; G Low, "A Numbers Game - The Legal 
relation with many of its applications to non-European transactions that have nothing to do with the establishment and functioning of the internal market, as the proposal intends; ${ }^{14}$ but the cynicism of the EU in matters related to its competences is well-known and no time will be taken here trying to reveal the true constitutional limits of European Union private law. In contrast, it is interesting to notice that Article 13(a) of PCESL enables Member States to broaden its application -and thus the parties' option- to purely domestic cases.

The material sphere of application of the CESL must be determined, firstly, by taking into account the type of contracts covered. Basically, these are sale of goods [goods are defined in Article 2 (h)], supply of digital contents, and related service contracts (Article 5 PCESL). The PCESL has left out mixed contracts (including any elements other than the sale of goods, the supply of digital content and the provision of related services) and those linked to a consumer credit contract, but instalment contracts are included (Article 6 PCESL). Secondly, attention must be paid to personal restrictions: contracts between traders and consumers (B2C) are included, and also between traders if one of them is a small or medium-size enterprise (SME) (as defined in the PCESL in accordance with the Commission Recommendation 2003/361 concerning the definition of micro, small and medium-size enterprises ${ }^{15}$ (Article 7 PCESL and Recital 21)). ${ }^{16}$ Member States are allowed to extend its application - and therefore enforce the parties' choice - to contracts between traders, even if neither is a SME [Article 13(b) PCESL].

Basis for an Optional Instrument on European Contract law", Maastricht European Private Law Institute (Working Paper No. 2012/2), < http://ssrn.com/abstract=1991070>; HW Micklitz \& N Reich, "The Commission's Proposal of a Regulation for an Optional 'Common European Sales Law' - Too broad or not broad enough?", EU Working Papers Law, 2012/4, <www.ssrnid2013183[1].pdf>, 4-11; D Staudenmayer, "Der Kommissionsvorschlag für eine Verordnung zum Gemeinsamen Europäischen Kaufrecht", NJW, 2011/48, 3491, 3495-3496; K Riesenhuber, "Der Vorschlag für eine Verordnung über ein 'Gemeinsames Europäisches Kaufrecht' - Kompetenz, Subsidiarität, Verhältnismäßkeit”, EWS, 2012/1-2, 8-10; WH Roth, "Der 'Vorschlag für eine Verordnung über ein Gemeinsames Europäisches Kaufrecht' (KOM (2011) 635 endg.), EWS, 2, 7, 14-21; K. Kroll-Ludwigs, "Ein optionales Vertragsrecht für Europa (Motor oder Hemmnis für den Binnenmarkt?", GPR, 2012/4, 181-183: M Hesselink, “The Case for a Common European Sales Law in an Age of Rising Nationalism", (2012) European Review of Contract Law 342, 366.

14 "This solution has as its objective the establishment and the functioning of the internal market. It would remove obstacles to the exercise of fundamental freedoms which result from differences between national laws, in particular from the additional transaction costs and perceived legal complexity experienced by traders when concluding cross-border transactions and the lack of confidence in their rights experienced by consumers when purchasing from another EU country, all of which have a direct effect on the establishment and functioning of the internal market and limit competition" (PCESL, 10).

15 OJ 2003 L124/36.

16 The optional character of the instrument and its scant attraction from the point of view of business transactions lead to pessimistic predictions about its competitiveness in the market of the "free choice of the applicable law". See e.g. T. Achermann, "Das Gemeinsame Europäische Kaufrecht - eine sinvolle Option für B2B-Geschäfte?”, Gemeinsames Europäisches Kaufrecht für die EU? (Analyse des Vorschlags der Europäischen Kommission für ein optionales Europäisches Vertragsrecht vom 11. Oktober 2011), Remien, Herrler and Limmer Hrsg. (Munich, C.H. Beck, 2012) 49-66. This pessimism seems justified even though the emergence of regulatory competition with regard to contract law regimes cannot be predicted with equal confidence compared with tax law or company law (see S Vogenauer, "Regulatory Competition through Choice of Contract Law and Choice of Forum in Europe: Theory and Evidence" (2013) European Review of Private Law 13-78). 
Finally, the optional character of CESL (Article 11 PCESL) implies that its application is conditional on a positive choice by the parties (opting in $)^{17}$, which -as has been said abovedoes not entail a choice of law in the sense of private international law, given that the option for CESL rules is only effective under a previous condition of application of the national law of a Member State designated by the rules of the Rome I Regulation. The choice made by the parties in favour of the CESL constitutes in any case an independent agreement whose validity is determined by Articles 8 and 9 PCESL and by the general rules on formation of contracts included in the CESL itself. Particularly, in the case of consumer contracts the choice will be enforceable only if consumer consent is given explicitly and separately and implies an entire (not partial) choice, provided that the trader has complied with the information duties required by Article 9 PCESL.

\section{CHOICE OF LEX CONTRACTUS}

\section{Choice of law under Article 3 of the Rome I Regulation}

The choice of the CESL by the parties involved in B2B relationships and in consumer contracts excluded from Article 6 of the Rome I Regulation does not guarantee the application of CESL rules, insofar as such a choice is only fully effective if the lex contractus is the law of a Member State. ${ }^{18}$ Otherwise, a choice of the CESL would not yield the effects stipulated in Article 11 PCESL:

${ }^{17}$ Recitals 22 and 23 state the basic principles that regulate such a choice: "22. The agreement of the parties to a contract is indispensable for the application of the Common European Sales Law. That agreement should be subject to strict requirements in business-to-consumer transactions. Since, in practice, it will usually be the trader who proposes the use of the Common European Sales Law, consumers must be fully aware of the fact that they are agreeing to the use of rules which are different from those of their pre-existing national law. Therefore, the consumer's consent to use the Common European Sales Law should be admissible only in the form of an explicit statement separate from the statement indicating the agreement to the conclusion of the contract. It should therefore not be possible to offer the use of the Common European Sales Law as a term of the contract to be concluded, particularly as an element of the trader's standard terms and conditions. The trader should provide the consumer with a confirmation of the agreement to use the Common European Sales Law on a durable medium. 23. In addition to being a conscious choice, the consent of a consumer to the use of the Common European Sales Law should be an informed choice. The trader should therefore not only draw the consumer's attention to the intended use of the Common European Sales Law but should also provide information on its nature and its salient features. In order to facilitate this task for traders, thereby avoiding unnecessary administrative burdens, and to ensure consistency in the level and the quality of the information communicated to consumers, traders should supply consumers with the standard information notice provided for in this Regulation and thus readily available in all official languages in the Union. Where it is not possible to supply the consumer with the information notice, for example in the context of a telephone call, or where the trader has failed to provide the information notice, the agreement to use the Common European Sales Law should not be binding on the consumer until the consumer has received the information notice together with the confirmation of the agreement and has subsequently expressed consent."

18 "The proposal provides for a single uniform set of fully harmonised contract law rules including consumer protection rules in the form of a Common European Sales Law which is to be considered as a second contract law regime within the national law of each Member State available in cross-border transactions upon a valid agreement by the parties. This agreement does not amount to, and must not be confused with, a choice of the applicable law within the meaning of private international law rules. Instead, this choice is made within a national law which is applicable according to the private international law rules." (PCESL, 9). 
"Where the parties have validly agreed to use the Common European Sales Law for a contract, only the Common European Sales Law shall govern the matters addressed in its rules. Provided that the contract was actually concluded, the Common European Sales Law shall also govern the compliance with and remedies for failure to comply with the pre-contractual information duties." 19

To some extent, therefore, a choice of the CESL is not only dependent on the choice of the applicable law, but it also requires such a choice of the law of a Member State if, in the absence of choice, Article 4 of the Rome I Regulation provides for the application of the law of a third State. It has rightly been pointed out that such a double-choice system can lead to legal uncertainty and provoke surprises for the parties. One can imagine, for instance, a sale concluded between a trader established in a third State and a SME established in a Member State, including a choice of CESL rules without an express choice of lex contractus. In this case, the law applicable under Article 4(1)(a) of the Rome I Regulation would be the law of the third State where the trader is established. As a result, this CESL choice would be ineffective -at least in the sense of Article 11 PCESL- and it would be considered as a mere incorporation by reference, whose rules might be excepted both by the national applicable law of the third State and by the very contract conditions individually concluded, that could contradict any CESL mandatory rules.

To avoid such a pernicious effect, it has been proposed that a choice of the CESL would imply a tacit choice of the law of a Member State, in the sense of Article 3(1) of the Rome I Regulation. ${ }^{20}$ At first sight, it seems a reasonable interpretation, but in fact it does not fit well within the principles, surely too classic and old-fashioned, that emerge from Recital 13 of the Regulation and from the insistence on only being able to choose a "national" law. Finally, a tacit choice always requires that the real choice of a specific State law can be clearly demonstrated. ${ }^{21}$ To reach such a conclusion, the wording of the contract and all the circumstances of the case must provide significant and clear signs, enough to identify a specific national law. In that case, the lex contractus will no longer be the law of the establishment of the trader (under Article 4), but the law chosen by the parties under

${ }^{19}$ The Committee on Legal Affairs of the European Parliament proposed the following amendment to make clear that the CESL qualifies as a second regime within the legal order of each member State: "Where the parties have validly agreed to use the Common European Sales Law for a contract, only the Common European Sales Law shall govern the matters addressed in its rules, instead of the contract law regime that would, in the absence of such an agreement, govern the contract within the legal order determined as the applicable law", Draft Report on the proposal for a regulation of the European Parliament and of the Council on a Common European Sales Law (COM(2011)0635 - C70329/2011 - 2011/0284(COD)), 41.

${ }^{20}$ See the reflections of G. Cuniberti in <http://conflictoflaws.net/2012/common-european-saleslaw-and-third-state-sellers $/>$ on $14^{\text {th }}$ February 2012, and also in $<$ http://conflictoflaws.net/2012/common-european-sales-law-third-states-and-consumers/> on $22^{\text {th }}$ February 2012. See M Fornasier, "28. versus 2. Regime -Kollisionsrechtliche Aspekte eines optionalen europäischen Vertragsrecht" (2012) Rabels Zeitschrift 401, 423; G Rühl, "The Common European Sales Law: 28th Regime or 1'st Regime?", Maastricht European Private Law Institute (Working Paper No. 2012/5), < http://ssrn.com/abstract $=2025879>$, 9.

${ }^{21}$ Writers agree that a choice of the CESL does not entail a choice of the applicable law under Article 3 of the Rome I Regulation. On the contrary, the abandoned " $28^{\text {th }}$ regime" formula not only contradicts the old-fashioned restriction of the choice of law to a national law, but also questions the application of other conflict-of-laws rules envisaged in Article 25 of the Rome I Regulation, such as those derived from the Hague Convention on the law applicable to contracts for the international sale of goods in force in some Member States. See M Schmidt-Kessel, supra n 9, 37; M Stürner, "Das Verhältnis des Gemeinsamen Europäischen Kaufrechts zum Richtlinienrecht", Der Entwurf für ain optionales europä̈sches Kaufrecht (Munich, 2012) 65; G Rühl, n 20, 3-6; M Fornasier, n 20, 415-416, 429-430. 
Article 3. In other words, the current rules of the Rome I Regulation will not be changed at all. That is why some authors suggest an amendment to Article 11 PCESL which favoured such an interpretation, presuming that the parties wanted to choose, for example, the national European law most closely connected with the contract. But this amendment would not only affect the PCESL, but also Article 3 of the Rome I Regulation itself, given that this rule does not allow such an objective perspective of the parties' will.

Furthermore, it is possible to imagine a choice of the applicable law of a third State and, at the same time, a choice of the CESL, where all relevant contacts are located within the European Union in the sense of Article 3(4) of the Rome I Regulation. The CESL could not be applied in this case due to Article 11 PCESL, because the applicable law is the law of a third State. The CESL could be considered a mere incorporation by reference and mandatory rules of any other European directives or regulations must be applied. ${ }^{22}$ Obviously, an alternative interpretation is that Article 3(4) of the Rome I Regulation -like Article 3(3)- applied where there is not a true choice of the law of a third State. In the case of Article 3(3), where all relevant contacts are located in a single Member State, in fact the true lex contractus is the law where all relevant factors are located. This law determines the extent of party autonomy and all its mandatory rules (not only its overriding mandatory rules) must be applied. The choice of the law of a third State has no true "conflict-of-laws" scope and it works as a mere incorporation by reference. Thus, the CESL choice could be considered fully effective in the sense of Article 11 PCESL, given that the true lex contractus is the law of a Member State. Article 3(4) requires a more subtle analysis. One can imagine a contract proposed by a trader located in a Member State to a SME located in another Member State including a choice of Californian law and a choice of the CESL. All relevant factors are situated in different Member States of the EU. The SME could accept the contract, being confident in the application of CESL rules even though they are contradicted in some points by Californian law. At first sight, under Article 11 PCESL the choice of CESL rules is not fully effective, insofar as Californian law is the lex contractus. CESL rules will be considered therefore as a mere incorporation by reference. In this case, the corrective interpretation proposed above in relation to Article 3(3) of the Rome I Regulation is not self-evident. Given that all relevant factors are located in different Member States it is not easy to determine the law of a Member State as the true lex contractus. In the proposed example, it is difficult to find a legal ground for the application of the CESL, apart from a mere incorporation by reference. Instead, mandatory rules included in other European directives or regulations must be applied, restricting the scope of Californian law. Finally, Article 3(4) of the Rome I Regulation would be more compatible with a sort of " $1{ }^{\text {st }}$ Regime", but a " $28^{\text {th }}$ Regime" will also guarantee the application of CESL rules chosen by the parties in a similar case and therefore legal certainty.

In the field of $\mathrm{B} 2 \mathrm{~B}$ relationships, there is another difficult question: the compatibility between the PCESL and the CISG. It is not a trivial question, insofar as there are relevant differences between both instruments. ${ }^{23}$ Under Article 1 CISG, its substantive rules can be

22 In contrast, if Member States have recourse to the option provided in Article 13(a) PCESL extending its application to domestic cases, a choice of CESL would lead to a paradox: the application of domestic mandatory rules (which cannot be derogated from by agreement) of the national law where all relevant elements are located would be defused.

${ }^{23}$ Among the most significant differences, the following have been pointed out: While Articles 2 and 3 CESL stipulate a generic duty to act in good faith, Article 7 CISG only mentions good faith as an element for contract interpretation. Article 31 CESL recognises the enforceability of an offer without a determinable or determined price, unlike Article 14 CISG. Article 31 CESL is clearer and much more categorical in recognising the irrevocable character of an offer which establishes a determined period for acceptance, in contrast to Article 16 CISG. Article 39 CESL includes a 
applied both directly — where the contracting parties are established in contracting Statesand indirectly —where the lex contractus is the law of a contracting State-. Among the Member States of the European Union, only Portugal, Malta, Ireland and the United Kingdom are not contracting States. Article 6 CISG requires an exclusion by the parties in such cases (opting out), and one can wonder what would happen if the parties choose the CESL rules without excluding the CISG. The most reasonable interpretation, in order to guarantee the legitimate expectation of the parties, is to consider that contracting parties have excluded the CISG by the choice of the CESL. ${ }^{24}$ That is suggested apparently by Recital 25 PCESL in several language versions, but not in the Spanish one that says just the opposite. ${ }^{25}$ Certainly, coincident versions use a modal verb that means recommendation or

special rule in case of a conflict of standard terms (battle of the forms) based on the "knock out rule", while the CISG is silent in this respect and presumably keeps in force the "last shot rule". Contrary to the CISG, the CESL regulates defects in consent. Chapter 6 CESL contains more detailed rules on contract interpretation than Article 8 CISG. Article 89 CISG recognises and deals with hardship effects, the treatment of which is quite doubtful in Article 79 CISG. Article 116 CESL includes the anticipatory breach of contract, which is unknown in the CISG. Section 3 of chapter 16 CESL provides solutions to late payment and interests unforeseen in the CISG. Such differences have been qualified as "improvements" by the European rules. See O Lando, "On a European Contract Law for Consumers and Business - Future Perspectives", Towards a European Contract Law, R Schulze and J Stuyck (eds.) (Munich, 2011) 205-206; Id., "CESL or CISG? Should the Proposed EU Regulation on a Common European Sales Law (CESL) Replace the United Nations Convention on International Sales (CISG)?”, Gemeinsames Europäisches Kaufrecht für die EU? (Analyse des Vorschlags der Europäischen Kommission für ein optionales Europä̈sches Vertragsrecht vom 11. Oktober 2011), Remien, Herrler and Limmer Hrsg. (Munich, 2012) 15-20; Id., "Comments and Questions Related to the European Commission's Proposal for a Regulation on a Common European Sales Law", European Review of Private Law, (2011) 717, 721-722; LA DiMatteo, "The Curious Case of Transborder Sales Law: A Comparative Analysis of CESL, CISG, and the UCC", CISG vs. Regional Sales Law Unification (With a Focus on the New Common European Sales Law), E Magnus (ed)( Munich, 2012) 25, 41-43; U Magnus, "CISG vs. CESL", CISG vs. Regional Sales Law Unification (With a Focus on the New Common European Sales Law) E Magnus (ed) (Munich, 2012) $97-$ 123; M B M Loos \& H Schelhaas, "Commercial Sales: The Common European Sales Law Compared to the Vienna Sales Convention", (2013) European Review of Private Law 105-130]. However, jurists who appreciate the deep-rooted tradition of the common law might disagree that these are improvements - especially in relation to irrevocable offers, the battle of the forms, hardship or contract interpretation-. Other generic differences, pointed out by S Whittaker, would be —apart from the different system of "opting-in/opting-out" - the essential non-mandatory character of CISG rules (Article 12), as opposed to the mandatory character of CESL rules (see $n$ 10, 393-394).

${ }^{24}$ M Fornasier, supra n 19, 428-429; R. Koch, "CISG, CESL, PICC and PECL", CISG vs. Regional Sales Law Unification (With a Focus on the New Common European Sales Law E. Magnus (ed) (Munich, 2012) 125, 141-143.

25 "Where the United Nations Convention on Contracts for the International Sale of Goods would otherwise apply to the contract in question, the choice of the Common European Sales Law should imply an agreement of the contractual parties to exclude that Convention." In French: "Lorsque la convention des Nations Unies sur la vente international de marchandises trouverait à s'appliquer au contrat en question, le choix de recourir au droit commun européen de la vente devrait impliquer l'accord des parties contractantes d'exclure cette convention." In German: "Sollte die Wabl des Gemeinsames Europä̈schen Kaufrechts eine Vereinbarung des Vertrags parteien dahingehend implizieren, dass die Anwendung dises übereinkommens ausgeschlossen wird". Strangely, the Spanish version of Recital 25 PCESL leads to the prevailing application of the CISG if there is not an express exclusion of this Treaty: "[C]uando sea aplicable a un contrato la Convención de las Naciones Unidas sobre los Contratos de Compraventa Internacional de Mercaderías, la elección de la normativa común de compraventa europea debe requerir un acuerdo de las partes contratantes para excluir la aplicación de dicha Convención". Translated literally into English it reads: "Where the United Nations Convention on Contracts for the International Sale of Goods would apply to a contract, 
possibility "(should imply, sollte implizieren, devrait impliquer), but it is undeniable that the aim is to exclude the CISG. However, the CISG requires an explicit "opting out" in those States that limited the scope of Article 11 CISG by virtue of the reserve made possible by Articles 12 and 96 CISG. Moreover, peremptory conditions to make such an exclusion under Article 6 CISG effective have been interpreted in different ways as regards tacit or implicit exclusions, although a restrictive perspective in this respect is only seen before USA courts $^{26}$. European courts usually maintain that a choice of the law of a non-contracting State implies an exclusion of the CISG, but the same consequence is not self-evident where the parties choose the law of a contracting State. In this last case, a generic choice of the national law of a contracting party does not mean an implicit exclusion of the CISG, which would be part of that law. The more reasonable approach is that a choice of the CESL must imply a tacit exclusion of the CISG, even if the law of a contracting party is applicable by virtue of a choice by the contracting parties or in the absence of such a choice. However, the case deals with a question of interpretation of the CISG itself ${ }^{27}$ and not of the CESL. Recital 25 is therefore beyond the scope of the PCESL because it interferes with the interpretation mechanism of an international Treaty which requires its own rules to be taken into account (Article 7 CISG). The universal character of the CISG interpretation is jeopardised by the lack of definition in Recital 25. This creates a source of conflicts ${ }^{28}$ and potential breaches of international obligations aw well as sowing legal uncertainty.

\section{Choice of law under Article 6 of the Rome I Regulation}

Together with transactions concluded by SMEs, PCESL's main goal is to facilitate intraEuropean consumer contracts. ${ }^{29}$ Under Article 4(3) PCESL, the scope of application of

the choice of the Common European Sales Law must require an agreement of the contractual parties to exclude the application of that Convention." Comparing this linguistic version with others, it seems clear that the wrong translation is the Spanish one, and that the intention of the proposal is to exclude the CISG when the contracting parties have chosen the CESL. Such an error leads obviously to mistaken interpretations: see E Fernández Masiá, "Optando por la Normativa Común de Compraventa Europea”, 23 Revista Electrónica de Estudios Internacionales, 2012, 1, 17.

${ }^{26}$ See Schlechtriem \& Schwenzer: Comentario sobre la Convención de las Naciones Unidas sobre los contratos de compraventa internacional de mercaderias, I Schwenzer and E Muñoz (eds), I, 2011, 298-320.

${ }^{27}$ See. M Hesselink, "How to Opt into the Common European Sales Law? Brief Comments on the Commission's Proposal for a Regulation", (2012) European Review of Private Law 195, 201-202; N Kornet, "The Common European Sales Law and the CISG - Complicating or Simplifying the Legal Environment?", Maastricht European Private Law Institute (Working Paper No. 2012/4, $<\underline{\text { http: } / / \text { ssrn.com } / \text { abstract }=2012310>, 7 .}$

${ }^{28}$ See M. Schmidt-Kessel, supra, n 2, 21-23.

29 "Differences in contract law between Member States hinder traders and consumers who want to engage in cross-border trade within the internal market" (PCESL, 1). "Thus, differences in contract law and the additional transaction costs and complexity that they generate in cross-border transactions dissuade a considerable number of traders, in particular SMEs, from expanding into markets of other Member States. These differences also have the effect of limiting competition in the internal market. The value of the trade foregone each year between Member States due to differences in contract law alone amounts to tens of billions of Euros. The missed opportunities for cross-border trade also have a negative impact upon European consumers. Less cross-border trade, results in fewer imports and less competitiveness between traders. This can lead to a more limited choice of products at a higher price in the consumer's market" (PCESL, 3). "Traders should be able to apply the Common European Sales Law in all their cross-border dealings within the European Union instead of having to adapt to different national contract laws, provided that the other party to the contract agrees.(...) As a direct consequence, traders could save on the additional contract law related transaction costs and could operate in a less complex legal environment for cross-border trade on the basis of a single set of rules across the European Union. Thus, traders would be able to 
CESL rules is significantly wider. The CESL is applied to consumer contracts where either the trader or the consumer have their habitual residence in a third State and even if both are resident in a third State (e.g. if only the billing address is located in a Member State). Obviously, consumer contracts protected under Article 6 of the Rome I Regulation can also be submitted by the parties to the CESL. Where the parties have chosen the applicable law, three different cases arise.

The first case arises where the contracting parties have chosen the law of a third State. Then, the choice of the CESL will be considered as an incorporation by reference, whose effects will be limited, insofar as the simple mandatory rules of the law of the habitual residence of the consumer, the mandatory rules of the law of the third State and the single negotiated terms, in this order, will prevail. In such a case, the CESL does not guarantee legal certainty of any contracting party. Consumers could be persuaded to make a choice of the CESL if this is a more favourable regime than that established by the law of their habitual residence, without suspecting that such a choice has only the value of an incorporation by reference and ignoring that CESL rules can be contradicted by the chosen lex contractus if the rules of his habitual residence are not more protective. Neither is it certain for traders, exposed to more favourable rules of the law of the consumer's habitual residence, whatever it may be. Application of the CESL is not guaranteed if the habitual residence of the consumer is located in a Member State because Article 6(2) of the Rome I Regulation leads to the peremptory application of the mandatory rules of the national law of that Member State. Notice that CESL rules will not be applied, in a narrow sense, due to the PCESL, but by virtue of an incorporation by reference. Although an interpretation that the CESL provides the threshold of consumer protection under Article 6(2) as against the law of the third State may be foreseen, there is no clear legal basis for such an interpretation.

The second hypothesis appears, on the contrary, where the parties choose the law of a Member State and also the CESL. The CESL would be the substantive rules applicable within the lex contractus, and would be exclusively considered to interpret and restrict all the contractual terms. The PCESL praises this result as the best way to achieve legal certainty and minimise external costs derived from conflict-of-law rules:

"Under the normal operation of the Rome I Regulation there are however restrictions to the choice of law for business-to-consumer transactions. If the parties choose in business-to consumer transactions the law of another Member State than the consumer's law, such a choice may under the conditions of Article 6(1) of the Rome I Regulation not deprive the consumer of the protection of the mandatory provisions of the law of his habitual residence (Article 6 (2) of the Rome I Regulation). The latter provision however can have no practical importance if the parties have chosen within the applicable national law the Common European Sales Law. The reason is that the provisions of the Common European Sales Law of the country's law chosen are identical with the provisions of the Common European Sales Law of the consumer's country. Therefore the level of the mandatory consumer protection laws of the consumer's

take better advantage of the internal market by expanding their trade across borders and, consequently, competition in the internal market would increase. Consumers would benefit from better access to offers from across the European Union at lower prices and would face fewer refusals of sales. They would also enjoy more certainty about their rights when shopping crossborder on the basis of a single set of mandatory rules which offer a high level of consumer protection" (PCESL, 4). The achievement of this goal through a mechanism so lengthy, complex and controversial as the CESL has often been questioned (see e.g. N Reich, "EU Strategies in Finding the Optimal Consumer Law Instrument" (2012) European Review of Contract Law 1, 29). 
country is not higher and the consumer is not deprived of the protection of the law of his habitual residence". 30

And Recital 12 insists:

"Since the Common European Sales Law contains a complete set of fully harmonized mandatory consumer protection rules, there will be no disparities between the laws of the Member States in this area, where the parties have chosen to use the Common European Sales Law. Consequently, Article 6(2) Regulation (EC) No 593/2008, which is predicated on the existence of differing levels of consumer protection in the Member States, has no practical importance for the issues covered by the Common European Sales Law". ${ }^{31}$

Such a conclusion, however, seems controversial. ${ }^{32}$ The "2 ${ }^{\text {nd }}$ Regime" implies a fork in the road in a "second step", when the conflict of laws rules have determined the application of the law of a Member State and parties have chosen CESL rules. The PCESL clearly suggests that the rules of the Rome I Regulation remain intact: "The Rome I Regulation and Rome II Regulation will continue to apply and will be unaffected by the proposal". ${ }^{33}$

However, the scope of this regime, under the PCESL Explanatory Memorandum, disregards in such a case the application of more protective rules of the law of the consumer's habitual residence and therefore modifies Article $6.2^{\circ}$ of the "Rome I" Regulation. According to some authors, to a large extent the avoidance of the so-called " $28^{\text {th }}$ Regime" was based precisely on the aim to achieve a harmonization avoiding the intervention of Article 6(2) of the Rome I Regulation. ${ }^{34}$ This article is not only a conflictof-laws rule. It is a conflict of laws rule with a substantive scope that entails a public policy orientation, a limit to the applicable law consisting in the application, by way of exception, of any more protective mandatory rule (not only "overriding") of the law of the consumer's residence. This principle is clearly derogated from by the PCESL on the presumption that the CESL provides for the harmonisation of consumer contracts with such a high level of protection for the consumer that such a limit is unnecessary. If the presumption is false, one must conclude that the PCESL puts legal certainty before consumer protection, that is, the interests of traders before the interests of consumers.

Contracting parties can choose English law and the CESL within English law. The fact that the consumer has his habitual residence in Germany, where the CESL is also in force, should not prevent his benefitting from the protective mechanism provided by Article 6 of

30 PCESL, 6. See C Moser, "Der Kommissionsvorschlag für eine Verordnung über ein Gemenisames Europäisches Kaufrecht", Gemeinsames Europäisches Kaufrecht für die EU? (Analyse des Vorschlags der Europä̈schen Kommission für ein optionales Europäisches Vertragsrecht vom 11. Oktober 2011), Remien, Herrler and Limmer Hrsg. (Munich, 2012) 13.

31 See C Busch, "Kollisionsrechtliche Weichenstellungen für ein Optionales Instrument im Europäischen Vertragsrecht", EuZW, 2011/17, 655, 657-659; S Leible, "Der räumliche-persönliche Anwendungsbereich des gemeinsames Europäischen Kaufrechts", Gemeinsames Europä̈sches Kaufrecht für die EU? (Analyse des Vorschlags der Europäischen Kommission für ein optionales Europäisches Vertragsrecht vom 11. Oktober 2011), Remien/Herrler/Limmer Hrsg., Munich, 2012, 27; P. Mankowski, supra n 4, 101; M Hesselink, supra n 27, 200; D Staudenmayer, supra n 13, 3495; C Castronovo, "Sulla Proposta di Regolamento relativo a un diritto comune europeo della vendita", Europa e diritto privato, 2012/2, 289, 296-297.

32 See in this regard M Schmidt-Kessel, supra n 9, 39-40; M Stürner, supra n 21, 65-68; M Stürner, "Kollisionsrecht und Optionale Instrument: Aspekte einer noch ungeklärten Beziehung", GPR, 2011/5, 236, 240; S. Whittaker, supra n 10, 387-392.

33 PCESL, 6.

${ }^{34}$ This was a clear warning from Max Planck Institute for Comparative and International Private Law, "Policy Options for Progress Towards a European Contract Law" (2011) Rabels Zeitschrift 371, 410. 
the Rome I Regulation. The threshold of protection of consumer rights is that established in the law of his habitual residence, applicable objectively. First of all, it is wrong that the CESL contains a higher level of consumer protection than the current level of protection provided by the European acquis itself. Some think that avoidance of Article 6(2) of the Rome I Regulation is not a worrying issue, insofar as the CESL guarantees a high level of protection that makes such an intervention unnecessary. ${ }^{35}$ However, such an opinion is doubtful in a double sense. On the one hand, nothing prevents a future evolution of derived European law from implementing further consumer protection remaining petrified in the CESL. On the other hand, although the existing consumer law tends to a full European harmonization, in some cases it does not prevent a higher protection implemented by national laws. Thus, the CESL does not entail an improvement of consumer remedies in the case of non-performance, particularly due to ambiguous concepts and general clauses of which the CESL abuses, limited rights in cases of lack of conformity, and gaps in the mechanism of evidence, claim, repair and replacement. ${ }^{36}$ Another example is the general reduction of the prescription period to two years, while such a period is longer for certain claims under derived European law. ${ }^{37}$ Consequently, the statement that the CESL provides the highest level or ceiling of consumer protection does not seem convincing. Such a circumstance must be evidenced issue-by-issue.

Moreover, in German law (and in any other law of a Member State), besides the CESL one can obviously find some rules that implement European directives harmonising consumer's rights, but in the European sphere there is still room for situations that are not harmonised or are harmonised through minimum standards. Therefore, some differences among national laws for consumer protection remain for particular cases. ${ }^{38}$ Then, the fact that contracting parties have chosen, as lex contractus, the law of a Member State, and CESL rules within that law, should not mean that they are lessening the protection guaranteed by the law of the consumer's residence, located in another Member State, to the level of protection of CESL rules.

Thus, if the statements of the Explanatory Memorandum are followed absolutely literally, the doorway to the lack of legal protection for consumers would be opened, ${ }^{39}$ regardless of guarantees and cautions established in Articles 8 and 9 PCESL about the

\footnotetext{
35 See M Fornasier, supra, n 20, 411-415 (available in <http://ssrn.com/abstract=188151076 >); S Leible, "Von einem Berg sowie Mäusen und anderen Tieren - das Optionale Instrument ante portas", Europäische Zeitschrift für Wirtschaftsrecht, 2011, 809; Id. "Kollisionsrecht und vertikaler Regulierungswettbewerb”, Rabels Z., 2012/2, 374, 396-398; D Staudenmayer, supra, n 13, 3497; C Busch, supra, n 31, 658.

${ }^{36}$ See R Feltkamp and F Vanbosselle, “The Optional Common European Sales Law: Better Buyer's Remedies for Seller's Non-performance in Sales of Goods?” (2011) European Review of Private Law 873-905.

${ }^{37}$ See HW Micklitz \& N. Reich, supra n 13, 84. See also K Kroll-Ludwigs, supra n 13, 183-186.

38 See in this sense G Rühl, supra n 20,10-11. As a matter of fact, derived European law itself questions the legal regime of CESL on the integrity of a consumer's will in his "opting in" (see in this sense S Whittaker, supra n 10, 387-392).

${ }^{39}$ Such a "social dumping" was already warned of by some authors: H Muir Watt and R SeftonGreen, "Fitting the Frame: an Optional Instrument, Party Choice and Mandatory/Default Rules", European Contract Law after the Common Frame of Reference HW Micklitz \& F Cafaggi (eds), (Northampton, 2010) 210; JW Rutgers, "An Optional Instrument and Social Dumping”, (2006) European Review of Contract Law 210, 211; JW Rutgers, "An Optional Instrument and Social Dumping Revisited" (2011) European Review of Contract Law 350-359; F Esteban de la Rosa \& O Olariu, "La aplicación de la Normativa Común de Compraventa Europea (CESL) a los contratos de consumo: nuevos desafíos para el sistema europeo de Derecho internacional Privado", InDret, 2013/1, 1, 12.
} 
informed consent of consumers and individually negotiated terms ${ }^{40}$ Restrictions to party autonomy in favour of consumers provided by Article 6 of the Rome I Regulation is based, obviously, on the presumption that a consumer contract is usually a non-negotiated contract, as consumer freedom is always limited. Sometimes, it is forgotten that a choice of CESL rules likewise requires a positive choice by the parties, which is only conceivable if it benefits traders. Of course, the intention of the PCESL is to offer traders an atractive legal instrument, able to reduce transaction costs through harmonizing the legal regime of their export transactions, in such as to compell the promotion of CESL choice. But it forgets that such a choice, combined with a choice of the applicable law, is also useful for depriving the consumer of a protection guaranteed by the law of his habitual residence that can be higher than that guaranteed by the CESL itself.

In this second case the choice of the law of a Member State turns the choice of the CESL into a fully effective option, but sacrifices consumer protection. On the contrary, if an extensive application of Article 6(2) is mantained, legal certainty may not be ensured if the trader remains exposed to the application of the more protective rules of the law of the consumer's habitual residence, given that the CESL neither replaces national laws, nor emphasises the level of European harmonisation, which has still kept different regimes derived from minimal standards that the Directive 2011/83/EU of the European Parliament and of the Council on consumer rights tries to correct. ${ }^{41}$

There is yet a third case: contracting parties choose CESL rules and the applicable law of a Member State, but the habitual residence of the consumer is located in a third State. ${ }^{42}$ This is the best hypothesis for consumers, because Article 6 of the Rome I Regulation does not prevent higher protection for the consumer under the law of his habitual residence. ${ }^{43}$ However, that is not the best way to avoid transaction costs, as presumably intended by the CESL. On the contrary, as in the other cases, such transaction costs are hidden and unexpected. A European trader would be inclined to believe that a combined choice of

${ }^{40}$ In fact, as confessed by the Commission itself, the goal of the CESL is to avoid the traders' transaction costs incurred by Article 6(2) of the Rome I Regulation: "Furthermore, in cross-border business-to-consumer transactions, Article 6(2) of the Rome I Regulation also requires traders which direct their activity to the consumer's country of residence -this could happen, for example by opening a website in the language of this country, by offering to sell in the consumer's currency or by using a top level domain name other than the one in the trader's country- to comply with the mandatory level of consumer protection in the consumer's country of residence. The trader may either apply the consumer's national law in its entirety or choose another law, in practice most likely its own law. However, even in the latter case the trader still needs to ensure compliance with the mandatory consumer protection provisions stemming from the consumer's national law, whenever they provide a higher level of protection. As a result, the trader's standard terms and conditions may have to be amended to the requirements of different countries." See Communication from the Commission to the European Parliament, the Council, the European Economic and Social Committee and the Committee of the Regions: A Common European Sales Law to Facilitate Cross-Border Transactions in the Single Market, COM 2011, 636 final, 4. The duty of information as a counterweight to the derogation of the protection guaranteed by Article 6(2) of the Rome I Regulation, once analysed in detail, "is not reasonably good for anything" (see the devastating analysis and the categorical concluding remark of $\mathrm{K}$ Riesenhuber, "Information über die Verwendung des Gemeinsames Europäischen Kaufrechts (Gedanken zum Harmonisierungskonzept)", GPR, 2012/1, 2-6, shared by S Whittaker, supra, n 11, 387-392).

${ }^{41}$ OJ L $30422^{\text {th }}$ November 2011.

${ }^{2}$ Cf. P Mankowski, supra, n 4, 101-102; S Carneloup, "Der Anwndungsbereich des Optionalen Instruments, die Voraussetzungen seiner Wahl un das Verhältnis zur Rom-I-VO”, ZEuP, 2013/3, $705,716$.

${ }^{43}$ See HW Micklitz \& N Reich, supra, n 13, 24-25. 
forum, applicable law and the CESL provides a harmonic regime for all his export transactions, but Article 6 of the Rome I Regulation could dash his hopes.

The above reflections show that PCESL is by no means a mere set of technical rules drawn up by scholars. It obeys a political orientation, which in fact ignores the often muchtrumpeted "social dimension" of European contract law where it deals with consumer protection. "It emphasizes, in the end, an approach far from the "constitutional" requirements of the single market and the European Charter of Fundamental Rights, as has been pointed out by $\mathrm{G}$ Alpa and $\mathrm{H} \mathrm{W} \mathrm{Micklitz}{ }^{45}$, echoing a wider denunciation against the procedure, doubtfully democratic, that has conducted the implementation of the whole of European private law. ${ }^{46}$

\section{THE CESL AND THE LAW APPLICABLE IN THE ABSENCE OF CHOICE}

In the field of $\mathrm{B} 2 \mathrm{~B}$ relationships -and also of $\mathrm{B} 2 \mathrm{C}$ relationships where they are not protected by Article 6 of the Rome I Regulation- the application of CESL rules in the absence of choice of the applicable national law will depend on the residence of the seller [Article 4(1)(a) of the Rome I Regulation]. If the seller has his habitual residence in a third State, whose law would be applicable, once again a CESL option turns into a mere incorporation by reference, limited as explained above. Such consequence is perfectly possible in many cases submitted to the CESL spatial sphere of application under Article 4 PCESL: it happens, for example, in B2B relationships, where only the buyer has the habitual residence in a Member State; and even more easily in unprotected consumer contracts, where only the billing or the delivery address is located in a Member State. It is not reasonable to believe that a choice of the CESL is relevant enough to justify the application of the exception clause (Article 4(3) of the Rome I Regulation) in favour of the law of a connected Member State, partly for the same reasons mentioned above in relation with the manipulation of a tacit choice and partly due to the restrictive character of such an exception.

In the absence of choice, contracts submitted to Article 6 of the Rome I Regulation will be governed by the law of the consumer's habitual residence. If this is the law of a third State, the CESL option leads again to a mere incorporation by reference, with the same limited effects as described above. If a CESL choice is interpreted as implying a tacit choice

\footnotetext{
${ }^{44}$ See M Kenny, L Gillis and J. Devenney, "The EU Optional Instrument: Absorbing the Private International Law Implications of a Common European Sales Law" (2011) 13 Yearbook of Private International Law 315, 342.

${ }^{45}$ See G Alpa, "Towards a European Contract Law", Towards a European Contract Law R Schulze and J Stuyck (eds.) (Munich, 2011) 23, 27; H W Micklitz, "A 'Certain Future' for the Optional Instrument", Towards a European Contract Law R Schulze and J Stuyck (eds.)(Munich, Sellier, 2011) 185-190.

${ }^{46}$ Relevant authors have highlighted a lack of legitimacy that characterises the implementation of European contract law. It is particularly advisable to read the "Manifesto" of the so-called "Study Group on Social Justice in European Private Law" ("Social Justice in European Contract Law: a Manifesto", (2004) 10 European Law Journal 653-674), signed by authors as well-reputed as G Alpa, M Barcellona, M Bussani. H Collins, S Grundmann, M Hesselink, C Joerges, D Kennedy, U Mattei, $\mathrm{G}$ Teubner and $\mathrm{T}$ Wilhelmsson, among others. Their prestige is enough to consider their warning as more than pure folklore. The "Manifesto" denounces the technocratic willingness that orients the uniform achievements in the field of European contract law, mainly inspired by the necessities of the functioning of the single market, and rightly proposes a multi-track approach that should take into account the role of contract law as a mechanism for distribution of wealth. In relation to the Draft Common Frame of Reference, the Manifesto underlines that it has been implemented by a jurist elite associated with lobbies and through a technocratic procedure under the influence of the strongest economic powers.
} 
of the law of a Member State - which possibly is not convincing, as mentioned above- in any case it will not be possible to avoid the application of the more protective rules of the applicable law of the third State where the consumer resides. Therefore, the legal certainty intended in the CESL is once again betrayed. ${ }^{47}$ On the contrary, at first sight if the applicable law is the law of a Member State, all doubts vanish, insofar as the choice of the CESL supersedes the domestic rules of the Member State where the consumer is resident. This conclusion is drawn from a literal interpretation of Article 6(2) of the Rome I Regulation, which only provides the application of the more protective rules of the law of a consumer's habitual residence in the case of a choice of the national law of another State. A choice of the CESL is not a "conflict-of-laws" choice in the sense of Article 6 of the Rome I Regulation. The CESL rules form part of the law of the consumer's habitual residence that must be applied in the absence of such a "conflict-of-laws" choice. However, this is a very cunning interpretation that does not comply with the true aim of Article 6 and poses the same problems analysed in cases where the parties have chosen the law of a Member State other than the State of the consumer's habitual residence. ${ }^{48}$

\section{E. THE CESL AND OVERRIDING MANDATORY RULES}

Another complex question deals with a possible application of overriding mandatory rules considered in Article 9 of the Rome I Regulation in the case of a CESL choice. ${ }^{49}$ On the one hand, CESL rules do not prevent the application of the conflict-of-law rules and particularly of the Rome I Regulation. On the other hand, a choice of CESL rules supersedes concurrent domestic rules on the law of sales of the national applicable law of a Member State. The question lies in determining whether overriding mandatory rules modifying, restricting or excluding CESL rules - of the lex for or of the law of the State where the contract has to be or has been performed — whichever it may be- are also superseded. ${ }^{50}$ Some authors have justified such exclusion on the necessity of a narrow understanding of an "overriding mandatory rule" that does not contradict the effectiveness and the primacy of harmonised law. ${ }^{51}$ Arguably, the complete and European Union character of CESL rules, chosen by the contracting parties, prevents European Union courts from applying any restrictive mandatory rule of the applicable law (necessarily the law of a Member State).$^{52}$ Consequently, a double choice of the CESL and of the law of a Member State should also facilitate evading overriding mandatory rules of the forum and of the law of performance. ${ }^{53}$ But such an understanding is not self-evident.

This question leads us to consider once again the relationship between CESL and the European Union acquis on consumer protection. ${ }^{54}$ The Commission's Communication

${ }^{47}$ See M Fornasier, supra, n 20, 424-425.

${ }^{48}$ See in this sense G Rühl, supra, n 20, footnote $36^{\text {th }}$.

${ }^{49}$ This question is not in doubt where it deals with rules on aspects that are excluded from the CESL, as illegality of contract. M Fornasier provides the example of a sale of weapons or cannabis (supran 20, 439). See also S Carneloup, supra n 42, 717-724.

50 In the general way, relationships between national overriding mandatory rules and optional private European law are far from being clear: see J Basedow, "Das fakultative Unionspirvatrecht und das internationale Privatrecht", Grenzen überwinden - Prinzipen bewabren (Festschrift für Bern von Hoffmann zum 70. Geburstag am 28. Dezember 2011), Bielefeld, 2011, 50, 60-61.

${ }^{51}$ See M Fornasier, supra n 20, 439-440. S Leible, supra n 31, 26; P Mankowski, supra, n 4, 102; C Busch, supra n 31, 659-660.

${ }_{52}$ M Schmidt-Kessel, supra, n 2, 39.

${ }^{53}$ See e.g. C Wendehorst, supra n 10, 32-33.

${ }^{54}$ See M Stürner, supra n 21, 72-74; C Herresthal, “Zur Dogmatik und Methodik des Gemeinsamen Europäischen Kaufrechts nach der Vorschlag der Kaufrechts-Verordnung”, Der Entwurf für ein optionales europäisches Kaufrecht, Munich, 2012, 88-90. 
seems to delimitate this relationship on the ground of limiting the application of the European Union acquis to domestic cases, whereas the CESL would be a separate regime confined to cross-border transactions:

"The proposal represents a complementary approach to that found in the existing acquis in the field of consumer protection. In the first instance, it incorporates and is consistent with those measures, albeit that it is not limited by minimum levels of protection that have been set. Secondly, given its limitation to cross-border contracts, it is not a replacement for the generally applicable acquis. There will therefore be a continuing need to develop consumer protection standards using the traditional harmonisation approach used in this area. In this respect, it can be expected that over time the two approaches will develop in tandem, and inspire one another." ${ }^{55}$

Reality, however, is much more irreducible. It is not controversial that the aquis remains intact in domestic cases. The burning question arises from its interaction with the CESL in cross-border transactions. Necessarily (Article 4 PCESL), such cases are connected to European territory, that is why directives and secondary rules are called upon to be applied under legal and case-law criteria of spatial application. ${ }^{56}$ The wide spatial application of the CESL means that, in many cases, European directives will not be applied, because there are not sufficient, or close enough, connections with the internal market, under the rules that establish the spatial scope of application of directives. But in many cases directives require to be applied. If attention is paid, for example, to the first paragraph of Article 25 of Directive 2011/83/EU of the European Parliament and of the Council on consumer's rights, a prevailing application of the acquis rules over the CESL seems quite clear. Such a provision, whose title is "imperative nature of the Directive" advises that "[i]f the law applicable to the contract is the law of a Member State, consumers may not waive the rights conferred on them by the national measures transposing this Directive. Any contractual terms which directly or indirectly waive or restrict the rights resulting from this Directive shall not be binding on the consumer." This rule covers all cases of application of the CESL, insofar as, as explained above, the choice of CESL rules presupposes that the lex contractus is the law of a Member State. Consequently, a CESL choice cannot completely avoid domestic rules of the national applicable law, because its rules implementing a Directive cannot be waived "directly or indirectly". At least, there is an evident contradiction between Article 25 of Directive 2011/83/EU and the possibility opened by the PCESL, which needs a clarification. Many authors insist that the CESL is a set of rules on consumer contracts put forward in a European Union Regulation, whose primacy and binding legal character supersedes overriding mandatory rules of directives as well as

${ }^{55}$ Communication from the Commission to the European Parliament, the Council, the European Economic and Social Committee and the Committee of Regions: A Common European Sales Law to Facilitate Cross-Border Transactions in the Single Market, COM 2011, 636 final, 10.

${ }^{56}$ See K. Riesenhuber, supra n 13, 11. Some directives, especially in the field of consumer contracts, include specific rules on spatial delimitation: e.g. Article 6(2) of Directive 93/13 (unfair terms), Article 12(2) of Directive 97/7 (distance contracts) or Article 7(2) of Directive 1999/44 (sale and associated guarantees). The absence of rules on spatial delimitation in secondary European Union law leads to an interpretation based on the interests of the internal market, which may determine the application of a directive despite the application of the law of a third state as lex contractus (Case C-381/98 Ingmar [2000] ECR I-9305). In any case, these rules of case-law criteria are not "conflictof-laws" rules in the sense of Article 23 of the Rome I Regulation. Such delimitation of the spatial sphere of application of a Directive does not affect the application of conflict-of-law rules, but determine its "Anwendungswille" or purpose to be applied to a concrete case. This is particularly significant in relation to Article 9 of the Rome I Regulation. 
domestic rules themselves. ${ }^{57} \mathrm{C}$ Busch graphically points out that an opt-in of CESL implies an opt-out of any other protecting rules derived both from domestic and European Union law in force within Member States. ${ }^{58}$ Even in such a case, the major premise of critical authors in relation to Article 6(2) of the Rome I Regulation becomes confirmed: the final result is a substantial backward step in the mechanisms of consumer protection achieved by virtue of European harmonisation. ${ }^{59}$

In a more general way, the question lies in determining if the European Union acquis rules can be taken into account, as overriding mandatory rules, in the sense of Article 9 of the Rome I Regulation. ${ }^{0}$ The PCESL and the Commission only referred to the complementary character of those rules, ${ }^{61}$ presumably as a constructive tool to fill gaps, which is hardly compatible with the closed, entire and autonomous character of CESL interpretation under Article 4 CESL. But the question lies now in determining if, apart from that complementary character, a limiting role of such rules can be recognised where they contradict or restrict CESL rules. This dilemma is not really different from the doubts that arise in relation to Article 6(2) of the Rome I Regulation. A trend favouring the integrity of the CESL maintains the avoidance of more protective overriding mandatory rules derived from secondary European Union law, which should remain confined to domestic cases. It must be noted that a substantive comparison between the level of protection of the CESL and of the European Union acquis is not determining in this sense -although there are cases in which the level of protection of CESL rules is unquestionably lower, as explained above-, because what is at stake at the end is a limitation of a future development of the European Union acquis, which will be constrained by the level of protection provided by the CESL, at least in cross-border transactions. One can, thus, predict a possible fork in the policies on consumer protection within the European Union: an increasing protection in domestic cases as opposed to a petrified protection in crossborder transactions. Such diversity does not fit within a reasonable legal harmonisation inspired by the functioning of the single market, whose natural trend is just the contrary: a gradual harmonisation of the consumer protection level in both domestic and cross-border transactions.

\section{F. INTERPRETATIVE AND CONSTRUCTIVE FUNCTION OF THE CESL}

Under Article 12(1)(a) of the Rome I Regulation, interpretation of contract is governed by the lex contractus. In the framework of its material sphere of application, the CESL is a complete regime. Of course, gaps are possible, but a reference to the lex contractus -particularly to the domestic rules of the applicable national law-in order to fill them or as default rules is forbidden. As Recital 29 points out:

\footnotetext{
${ }^{57}$ See the reflections of J Basedow to contradict the arguments of S Whittaker (supra n 10, passim.), who maintains a contradiction between the CESL and the Directive 93/13 in relation with the illegality of the opting-in clause itself, on the ground of the legal and non contractual character of the validity of such a clause: "The Optional Instrument of European Contract Law: Opting-in through Standard Terms - A Reply to Simon Whittaker" (2012) European Review of Contract Law 8287.

58 Supra n 31, 660.

${ }^{59} \mathrm{~J}$ Basedow distinguishes, in fact, his technical opinion from a negative opinion on the results of the legal policy (supra $\mathrm{n} 57,87)$.

${ }^{60}$ For more details see S Sánchez Lorenzo, "Choice of Law and Overriding Mandatory Rules after Rome I" (2010) 12 Yearbook of Private International Law 77-79.

${ }^{61}$ See Communication from the Commission to the European Parliament, the Council, the European Economic and Social Committee and the Committee of Regions: A Common European Sales Law to Facilitate Cross-Border Transactions in the Single Market, COM 2011, 636 final, 1011; PCESL, Recital 28.
} 
"Once there is a valid agreement to use the Common European Sales Law, only the Common European Sales Law should govern the matters falling within its scope. The rules of the Common European Sales Law should be interpreted autonomously in accordance with the wellestablished principles on the interpretation of Union legislation. Questions concerning matters falling within the scope of the Common European Sales Law which are not expressly settled by it should be resolved only by interpretation of its rules without recourse to any other law. The rules of the Common European Sales Law should be interpreted on the basis of the underlying principles and objectives and all its provisions." 62

Obviously, the aim of the PCESL is to guarantee the uniform application of CESL rules in all Member States, trying to prevent, as far as possible, any "national" interpretation and being aware of the significance of uniform interpretation to achieve the main goal of a common European Union law on sales. No matter how logical this intent is, it remains unrealistic, as B Fauvarque-Cosson has pointed out. ${ }^{63}$ The CESL has not developed a catalogue of general principles, which any legal system needs to fill gaps and precisely to deserve the name of a "legal system". Consequently, an order to fill "internal gaps" of CESL according to their own principles and rules is hollow, insofar as such principles are not recognisable. They are not recognisable because the CESL, as a good example of a uniform text, gets around comparative divergences between European national laws, obtaining concrete rules whose content is more or less clear, but provokes at the same time a wide margin of oscillation that prevents it from filling gaps through hypothetical principles that are not really recognisable. ${ }^{64}$ Moreover, it seems highly pretentious, if not preposterous, to intend to establish a "complete" regulation where the legal text is limited to sales and a few related contracts. A legal regime can be complete and autonomous only when it has at its disposal enough contructive elements to fill gaps. Each national contract law provides such elements and principles, which underlie contract law as a whole, and can be found also in tort law or in the law of property. ${ }^{65}$

It must be taken into account that some aspects of sales are excluded from the material sphere of application of the proposal (external gaps). Domestic rules of the applicable law

62 The legal implementation of such a postulate can be found in Article 11 PCESL: "Where the parties have validly agreed to use the Common European Sales Law for a contract, only the Common European Sales Law shall govern the matters addressed in its rules. Provided that the contract was actually concluded, the Common European Sales Law shall also govern the compliance with and remedies for failure to comply with the pre-contractual information duties." Also in Article 4 CESL: "1. The Common European Sales Law is to be interpreted autonomously and in accordance with its objectives and the principles underlying it. 2. Issues within the scope of the Common European Sales Law but not expressly settled by it are to be settled in accordance with the objectives and the principles underlying it and all its provisions, without recourse to the national law that would be applicable in the absence of an agreement to use the Common European Sales Law or to any other law. 3. Where there is a general rule and a special rule applying to a particular situation within the scope of the general rule, the special rule prevails in any case of conflict."

${ }^{63}$ See "A Step Further in a Long and Incremental Process: The Feasibility Study of the Expert Group on European Contract Law", Towards a European Contract Law, R Schulze and J Stuyck (eds.) (Munich, 2011) 173, 175. See also the reservations of H W Micklitz, supra n 45, 181, 185; J M Smits, "The Common European Sales Law (CESL) Beyond Party Choice", ZEuP, 2012/3, 904, 912-913. In this sense, the delimitation of the scope of good faith is the example proposed by $\mathrm{F}$. Esteban de la Rosa \& O Olariu, supra n 39, 12-13.

${ }^{64}$ For a more developed treatment of this question see SA Sánchez-Lorenzo, Derecho privado europeo, (Granada, 2002) 162-169.

65 As has been pointed out since the first steps of European Private Law (see T Koopmans, Towards a European Civil Code (1997) European Review of Private Law 544). 
will be applied to such aspects. ${ }^{66}$ Some of them can be considered "contractual" and then they will be submitted to the Rome I Regulation, while others are characterised as noncontractual (governed by the Rome II Regulation) or related to the law of persons or goods (determined by the applicable law under domestic conflict-of-law rules in force in each forum).$^{67}$ Excluded questions are often not clearly delimited and imply a combination of divergent rules and a gap filling procedure based on those different laws.

Even in relation to matters clearly included in the CESL sphere of application, such as the validity of electronic contracts, the autonomous and complete character of the CESL is relative, insofar as the PCESL itself affirms the significance of European Union rules on electronic commerce. ${ }^{68}$ Indeed, the CESL is considered a part of the European Union acquis, ${ }^{69}$ and it intertwines with derived or secondary European Union law to provide a uniform interpretation. However, relationships between the CESL and the secondary European Union law on consumer protection are not clearly established in the PCESL. Moreover, the lack of formal and conceptual coherence between the CESL and the European union acquis, particularly in the field of consumer protection, hardly allows an interpretative reference to secondary European Union law. ${ }^{70}$

CESL choice leads to the application of its own rules and principles -barely deducible in case of gaps-, combined with a reference to directives and rules from secondary European Union law that govern different kinds of contracts. Aspects, contractual or not, excluded from the CESL sphere of application require an application of national rules, quite often designated by common rules on conflict-of-laws and occasionally by domestic conflict-oflaws rules. Affirming that the CESL is a fine mechanism for legal harmonisation that simplifies and provides legal certainty in cross-border transactions does not seem convincing, given the material and spatial spheres of application of the CESL and the complex and hard process of contract construction.

\section{G. FINAL REMARKS}

\footnotetext{
${ }^{66}$ See. C Busch, supra n 31, 660.

${ }^{67}$ Recital 27 specifies: "All the matters of a contractual or non-contractual nature that are not addressed in the Common European Sales Law are governed by the pre-existing rules of the national law outside the Common European Sales Law that is applicable under Regulations (EC) No 593/2008 and (EC) No 864/2007 or any other relevant conflict of law rule. These issues include legal personality, the invalidity of a contract arising from lack of capacity, illegality or immorality, the determination of the language of the contract, matters of non-discrimination, representation, plurality of debtors and creditors, change of parties including assignment, set-off and merger, property law including the transfer of ownership, intellectual property law and the law of torts. Furthermore, the issue of whether concurrent contractual and non-contractual liability claims can be pursued together falls outside the scope of the Common European Sales Law."

68 PCESL, 5: "Some Union legislation is relevant for both business-to-consumer and business-tobusiness relations. The E-commerce Directive contains rules on the validity of contracts concluded by electronic means and on certain pre-contractual requirements." It deals with Directive 2000/31/EC of the European Parliament and of the Council of 8 June 2000 on certain legal aspects of information society services, in particular electronic commerce, in the Internal Market, OJ $2000 \mathrm{~L} / 178$.

${ }^{69}$ See in this sense M Schmidt-Kessel, supra n 2, 15-21; Id., Common European Sales Law (CESL) -Commentary- R Schulze (ed)(Baden-Baden, 2012) 95.

${ }^{70}$ See B Gsell, "Der Verordnungsentwurf für ein Gemeinsames Europäisches Kaufrecht und die Probelematik seiner Lücken", Gemeinsames Europäisches Kaufrecbt für die EU? (Analyse des Vorschlags der Europäischen Kommission für ein optionales Europäisches Vertragsrecht vom 11. Oktober 2011), Remien, Herrler and Limmer Hrsg., (Munich, 2012) 151- 153.
} 
The same error of each attempt to harmonise European contract law hangs over the CESL from the beginning. Perhaps it can be named the "German disease", that is the stubbornness in unifying the consumer contract regime together with the commercial contract regime. Protective rules on consumer contracts do not easily fit within commercial contracts, even with SMEs. ${ }^{71}$ In a general way, the PCESL does not take seriously the competitiveness between legal orders, given its limited spatial and material sphere of application, its endless questions and the legal uncertainty derived from its inextricable relationships with conflict-of-law rules. CESL rules are not attractive in terms of legal certainty -at least in business transactions - ${ }^{72}$ and will not be able to replace more traditional options searching for legal systems that are less interventionist and are more predictable. $^{73}$ As a matter of fact, if both fields of transactions are separated, more reasonable and effective proposals to achieve a true revitalisation of international contracts could be found.

In $\mathrm{B} 2 \mathrm{~B}$ relationships an open competitiveness between legal orders is advised and the harmonising horizon can be more flexible. In this field, a wider party autonomy able to designate a non-national law as the applicable law must be promoted. This implies overruling the retrograde understanding that parties cannot choose a non-national law found in Recital 14 and Article 3 of the Rome I Regulation and to allow a choice as lex contractus not only of the CESL, but also of the CISG (where it is not directly applicable), UNIDROIT Principles, Principles of European Contract Law or the Common Frame of Reference. In this sense, a chance to choose the CESL as lex contractus, as a true "conflictof-laws" choice ( $28^{\text {th }}$ option), seems a more reasonable and efficient approach in B2B relationships.

Some authors prefer a more daring approach — called "first regime" - towards a uniform regime, without distinctions, along the lines of the direct application provided by Article 1(1)(a) CISG. Such an approach is extremely interventionist in B2B relationships and is not in accordance with the peremptory flexibility that arises from party autonomy in business transactions, unless a narrow optional character is kept. In B2C relationships such an "optional bet" openly implies a renunciation of the protection rule of Article 6(2) of the Rome I Regulation, which leads to a delicate decision in the current status of European Union law. For consumer contracts, the current powers of the European Union and the achieved degree of harmonisation support a more daring approach towards a true European Code of Consumer Law, which definitively would derogate and reformulate the whole European Union acquis through a common regulation in force in both domestic and cross-border transactions, dismissing in such a way any significance of Article 6(2) of the Rome I Regulation where the consumer has his habitual residence in a Member State.

\footnotetext{
${ }^{71}$ See e.g. the pertinent opinions of $\mathrm{N}$ Kornet, supra n 27, 13-17.

${ }^{72}$ See a negative or critical verdict on the CESL in terms of competitiveness and ability to reduce transaction costs in EA Posner, "The Questionable Basis of the European Common Sales Law: The Role of an Optional Instrument in Jurisdictional Competition", Chicago Institute for Law and Economics Working Paper N. 597 (2d. Series), May 2012, < http://ssrn.com/abstract=2049594>; also JM Smits, "Party Choice in European Common Sales Law, or: How to Prevent the CESL from Becoming a Lemon on the Law Market", Maastricht European Private Law Institute (Working Paper N. 2012/13), http://ssrn.com/abstract=2060017; G. Wagner, "Ökonomische Analyse des CESL: Das Recht zur zweiten Andienung", ZEuP, 2013/2, 797-825.

73 Obviously, the learning function of errors has been disregarded. The limited success of other optional instruments, like the UNIDROIT principles or the Principles of European Contract Law, have not been taken into account (see for more details S Sánchez Lorenzo, "La unificación del Derecho contractual y su problemática: la respuesta de la Unión Europea", Derecho contractual europeo: problemática, propuestas y perspectivas, (Barcelona, 2009) 106-114; and also the confession of O Lando himself, "Comments...", supra n 23, 719-720).
} 
Finally, in the field of business contracts with SMEs, considered as weak parties in nonnegotiated contracts, a middle term between uniform law and party autonomy would be minimum harmonisation through protective rules in European Union directives, as happens, for example, in agency contracts.

Last but not least, one cannot forget, although it has been omitted in this paper, that international harmony of decisions cannot be achieved where claims are taken before the courts of a third State. The complexity of the CESL will strike more and more in this case, which calls for a particular and more detailed analysis. ${ }^{74}$

In short, many experts agree with the convenience of the CESL despite its imperfections. My friend S Leible quoted in this respect a German saying: "Besser ein Spatz. in der Hand als eine Taube auf dem Dach". ${ }^{75}$ It could be translated into English: "A bird in the hand is worth two in the bush", but I prefer the literal meaning: "A sparrow in the hand is worth a pigeon on the roof". The question is simple. Who wants a sparrow in the hand and who is worried about a pigeon on the roof, where a delicious pheasant already roasted is waiting for us in the oven? As an option is possible, I bet the sparrow will fly off like a shot...

\footnotetext{
${ }^{74}$ See an outline in P Mankowski, supra n 4, 104-105.

75 "Von einem Berg sowie Mäusen und anderen Tieren - Das optionale Instrument ante portas", EuZW, 2011/21, 810.
} 